\title{
ANALISIS KAPASITAS PARKIR DI SEKITAR STASIUN BOGOR
}

\section{PARKING CAPACITY ANALYSIS AT AROUND BOGOR STATION}

\author{
Syaiful $^{1,}$, Rulhendri ${ }^{2}$, Achmad Syaifudin ${ }^{3}$ \\ ${ }^{1,2,3}$ Program Studi Teknik Sipil Fakultas Teknik Universitas Ibn Khaldun Bogor \\ ${ }^{1}$ Mahasiswa Program Doktor PSL Institut Pertanian Bogor \\ Alamat korespondensi : \\ email: syaiful@ft.uika-bogor.ac.id ; rulhendri@gmail.com ; achmadsyaifudin@gmail.com
}

\begin{abstract}
The level of customer satisfaction on the quality of parking service services in terms of five aspects, namely tangible ability, reliability, responsiveness, assurance, and empathy. The field survey method (field research) is direct observation around Bogor Station through the spread of surveyors at the points of observation (cordon count). Survey results are analyzed using Microsoft Excel program. Taking data by recording the number of incoming and outgoing motor vehicles at a certain time. Obtain parking capacity to be used in the calculation of the existing parking capacity of the survey (409 SRP) for the motorcycle parking at A and 247 SRP for motorcycle parking at site $B$. The research results show that the maximum volume of parking reaches 414 motorcycles for parking $A$ and 360 motor for parking $B$. The highest accumulation reaches 384 motorcycles for motorcycle parking $A$ and 305 motorcycles for parking B. Parking space utilization from Parking Turn Over reaches an average of 0.964 for parking $A$ and 1,416 for parking $B$. If parking space requirement is greater than the availability capacity, the number of parking spaces is not sufficient. Vice versa, if the need for parking space is smaller than the capacity available means that the amount of parking space is still able to accommodate vehicles to be parked.
\end{abstract}

Keywords: Level of Satisfaction, Service, Parkir.

\begin{abstract}
Abstrak
Tingkat kepuasan konsumen terhadap kualitas pelayanan jasa parkir ditinjau dari lima aspek yaitu Kemampuan Ujian (tangible), kemampuan nyataan (reliability), kecepatan tanggapan (responsiveness), jaminan (assurance), dan kepedulian (empathy). Adapun metode survei di lapangan (field research) yaitu pengamatan langsung di sekitar Stasiun Bogor melalui penyebaran surveyor pada titik-titik pengamatan (cordon count). Hasil survei dianalisis menggunakan program Microsoft Excel. Pengambilan data dengan cara mencatat jumlah kendaraan bermotor yang masuk dan keluar pada waktu tertentu. Didapatkan kapasitas parkir untuk digunakan dalam perhitungan kapasitas parkir survei (eksisting) sebesar 409 SRP untuk parkir motor di tempat A dan 247 SRP untuk parkir motor di tempat B. Hasil penelitian menunjukan bahwa volume maksimum parkir mencapai 414 motor untuk parkiran A dan 360 motor untuk parkiran B. Akumulasi tertinggi mencapai 384 motor untuk parkiran motor A dan 305 motor untuk parkiran B. Penggunaan ruang parkir ditinjau dari Parking Turn Over mencapai rata-rata 0,964 untuk parkiran A dan 1,416 untuk parkiran B. Jika kebutuhan ruang parkir lebih besar dari kapasitas tesedia maka jumlah ruang parkir tersebut tidak mencukupi. Demikian sebaliknya, apabila kebutuhan ruang parkir lebih kecil dari kapasitas tersedia berarti artinya jumlah ruang parkir masih mampu menampung kendaraan yang akan parkir.
\end{abstract}

Kata kunci: Tingkat Kepuasan, Pelayanan, Parkir.

\section{PENDAHULUAN}

Permintaaan parkir sepeda motor telah menjadi permasalahan besar di kota-kota besar dunia khususnya di negara tropis dan subtropis termasuk di Indonesia. Permasalahan timbul terutama karena kebutuhannya meningkat secara drastis setiap tahun. Sejalan dengan pertumbuhan penggunaan sepeda motor di Indonesia. Untuk memenuhi kebutuhan ruang parkir sepeda motor di kawasan perkantoran, terminal ataupun stasiun kereta api. Ada peluang usaha baru berupa penitipan motor dirumah atau ruko. Padatnya sepeda motor 
dan sistem perparkiran yang tidak mudah di Stasiun Bogor maka para pengguna sepeda motor mengalihkannya untuk parkir di rumah atau ruko di jalan Nyi Raja Permas (Jalan Mayor Oking Jayaatmaja) dekat Stasiun Bogor. Banyaknya tempat parkir yang berada di rumah atau ruko dekat Stasiun Bogor maka perlu dikaji pelayanan parkir. Pelayanan parkir adalah dua komponen penting dan tidak bisa dipisahkan dalam mencapai tingkat kepuasan pengguna jasa parkir pada sistem perparkiran yang baik.

Tujuan penelitian ini adalah, mendapatkan SRP parkir pada Areal parkiran A dan parkiran B, akumulasi parkir pada saat penelitian, kebutuhan parkir pada parkiran A dan parkiran $\mathrm{B}$, jumlah maksimum kendaraan pada parkiran A dan parkiran B dan mendapatkan hasil dari parikiran diluar dan didalam stasiun Bogor. Kebutuhan Ruang Parkir adalah jumlah tempat yang dibutuhkan untuk menampung kendaraan yang membutuhkan parkir berdasarkan fasilitas dan fungsi dari sebuah tata guna lahan. Untuk mengetahui kebutuhan parkir pada suatu kawasan yang di studi, terlebih dahulu perlu diketahui tujuan dari pemarkir (Abubakar, I, 1998). Volume parkir adalah jumlah keseluruhan kendaraan yang menggunakan fasilitas parkir, biasanya dihitung dalam kendaraan yang parkir dalam satu hari (Abubakar, I, 1998). Secara umum pelaksanaan penelitian ini dilaksanakan dalam beberapa tahap. Tahapan pengumpulan data baik primer maupun sekunder, data primer diperoleh dengan melakukan pencatatan pada titik pengamatan (Cordon Count) dan data sekunder yang di butuhkan adalah Site Plan/Peta Situasi lokasi Penelitian. Dalam pelaksanaan permodelan untuk simulasi, dilakukan identifikasi keberadaan sistem untuk perolehan gambaran tentang sistem yang dikaji dalam bentuk diagram skematis masukan-keluaran (inputoutput) (A.I. Syahidina, A. Goeritno dan Syaiful, 2017).

Tujuan Parkir yaitu, memberikan tempat istirahat kendaraan, menunjang kelancaran arus lalu lintas (Direktorat Jenderal Perhubungan Darat, 1996). Satuan Ruang Parkir adalah tempat parkir untuk satu kendaraan. Pada tempat dimana parkir dikendalikan maka ruang parkir harus diberi marka pada permukaan jalan.
Penentuan Satuan Ruang Parkir didasarkan kepada jenis kendaraan, ukuran ruang parkir dalam meter persegi (Direktorat Jenderal Perhubungan Darat, 1998). Dalam penelitian ini menggunakan pengumpulan data atau penelitian hanya elemen sampel (sebagian dari elemen populasi) yang di teliti, hasilnya merupakan data perkiraan (estimate). Sampel hanya mencatat, menyelediki sebagian objek, gejala atau peristiwa dan tidak seluruhnya. Tujuan teori sampel adalah membuat penelitian menjadi efisien, artinya biaya lebih rendah diperoleh tingkat ketelitian yang sama tinggi atau dengan biaya yang sama diperoleh tingkat ketelitian yang lebih tinggi (Hermawan, Warsito, 1995). Juga mengadakan wawancara langsung kepada pengemudi kendaraan dengan data-data nomer registrasi kendaraan, klasifikasi kendaraan, waktu kendaraan masuk, waktu kendaraan keluar, tujuan utama parkir dan kondisi lokasi parkir dan data lainnya (Hobbs, F.D, 1995). Kepuasan adalah tingkat kepuasan seseorang setelah membandingkan kinerja atau hasil yang dirasakan dibandingkan dengan harapannya. Jadi kepuasan atau ketidakpuasan adalah kesimpulan dari interaksi antara harapan dan pengalaman sesudah memakai jasa atau pelayanan yang diberikan (Kotler dkk, 2008). Kepuasan konsumen adalah hasil yang dirasakan oleh pembeli yang mengalami kinerja sebuah perusahaan yang sesuai dengan harapannya (Kotler, Philips, 200). Keuntungan dalam penggunaan sampel (Marzuki, 1997). Yaitu menghemat biaya, waktu, dan tenaga, biaya lebih murah, waktu lebih pendek, tenaga yang diperlukan lebih sedikit.

Dalam parkir juga ada standar pelayanan minmum SPM berdasarkan tabel 1 dibawah ini (Menteri Permukiman dan Prasarana Wilayah, 2001).

Tabel 1 Pedoman Penentuan Standar Pelayanan Minimal (SPM)

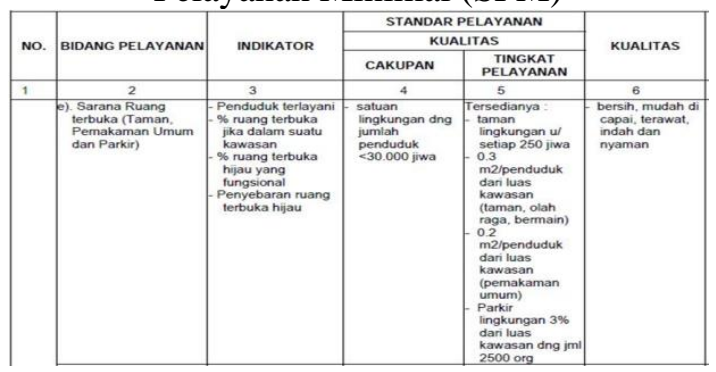


Tingkat pergantian parkir adalah laju pemakaian tempat parkir dalam periode tempat tertentu. PTO dapat diperoleh dengan cara jumlah kendaraan yang telah memanfaatkan lahan parkirpada selang waktu tertentu dibagi dengan ruang parkir yang tersedia (Oppenlender J.C and P.C. Box, 1976). Tarif parkir merupakan alat yang sangat bermanfaat untuk mengendalikan jumlah kendaraan yang parkir. Tarif parkir ditangani dengan cara yang biasa dilakukan di Indonesia yaitu oleh petugas parkir (juru parkir atau jukir). Sampai 1 Juli 2012, tarif parkir didasarkan pada peraturan daerah (Peraturan Daerah Kota Bogor, 2008). Dengan mobil membayar Rp 2.000 dan sepeda motor membayar Rp 1.000. Tarif ini tidak berdasarkan waktu. Tapi baru-baru ini di kota-kota Indonesia mempraktekan peningkatan tarif dengan meminta tarif lebih tinggi dari pengendara yang tetap selama lebih dari satu atau dua jam. Jadi dalam prakteknya, ada kemungkinan untuk pemberlakuan tarif progressif sebelum memberlakukan perubahan tari secara menyeluruh. Karena kekhawatiran tentang dampak parkir ganda dan bongkar/muat di Jalan Suryakencana, keputusan diambil untuk menaikan tarif parkir tiga kali lipat di sepanjang jalan itu. Ini dilaksanakan pada awal Juli 2012. Sayangnya, tidak ada data mengenai tingkat okupansi parkir dan jangka waktu untuk menggambarkan kondisi sebelum dan sesudah perubahan tarif. Struktur tarif baru berdasarkan perda adalah Rp 6.000 (mobil), Rp 3.000 (sepeda motor) (Peraturan Daerah kota Bogor, 2012). Akumulasi parkir merupakan jumlah kendaraan yang diparkir pada suatu tempat pada waktu tertentu dan dapat dibagi sesuai dengan kategori jenis dan maksud perjalanan, dimana integrasi parkir pada suatu periode tertentu, menunjukkan beban parkir (jumlah kendaraan parkir) dalam satu jam kendaraan per periode waktu tertentu (Raharjo, A.D.A, 2011). Pelayanan sepeda motor, angkutan umum dan non angkutan umum di Bogor merupakan target utama termasuk kecepatan sepeda motor dan angkutan lainnya (Syaiful, 2005; Syaiful, S., Elvira, Y, 2017; Syaiful, S., \& Rulhendri, R., 2014). Seiring dengan meningkatknya jumlah kendaraan bermotor di kota Bogor semakin bertambah juga kebutuhan parkir (Syaiful, 2015; Syaiful, S.T., M.T., 2016). Pengertian "parkir" secara umum adalah suatu keadaan tidak bergeraknya kendaraan secara permanen (Tobing, David M.L, 2007). Pelayanan publik adalah kegiatan atau rangkaian kegiatan dalam rangka pemenuhan kebutuhan pelayanan sesuai dengan peraturan perundangundangan bagi setiap warga negara dan penduduk atas barang, jasa, dan atau pelayanan administratif yang disediakan oleh penyelenggara pelayanan publik. Standar pelayanan adalah tolok ukur yang dipergunakan sebagai pedoman penyelenggaraan pelayanan dan acuan penilaian kualitas pelayanan sebagai kewajiban dan janji penyelenggara kepada masyarakat dalam rangka pelayanan yang berkualitas, cepat, mudah, terjangkau, dan terukur (Undang-undang Republik Indonesia, 2009). Indeks parkir merupakan persentase dari akumulasi jemlah kendaraan pada selang waktu tertentu dibagi dengan ruang parkir yang tersedia dikalikan dengan $100 \%$. Besarnya indeks parkir yang tertinggi diperoleh dari perbandingan antara akumulasi parkir dengan kapasitas parkir. Besaran indeks parkir ini akan menunjukkan apakah kawasan parkir tersebut bermasalah atau tidak (Warpani, S, 1990). Karakteristik parkir dimaksudkan sebagai sifat - sifat dasar yang memberikan penilaian terhadap pelayanan parkir dan permasalahan parkir yang terjadi pada daerah studi. Berdasarkan karakteristik parkir, akan dapat diketahui kondisi perparkiran yang terjadi pada daerah studi seperti mencakup volume parkir, akumulasi parkir, tingkat pergantian (turn over paking) dan tingkat penggunaan (occupancy rate), dan indeks parkir. Informasi mengenai karakteristik parkir sangatlah diperlukan pada saat kita merencanakan suatu lahan parkir (Z, Tanmin, Ofyar, 1997).

\section{METODE PENELITIAN}

Tahapan ketiga adalah pengolahan data analisis dengan program Microsoft Excel. Secara umum tahapan kegiatan penelitian yang dilaksanakan ditunjukan oleh Gambar 1 berikut ini. 


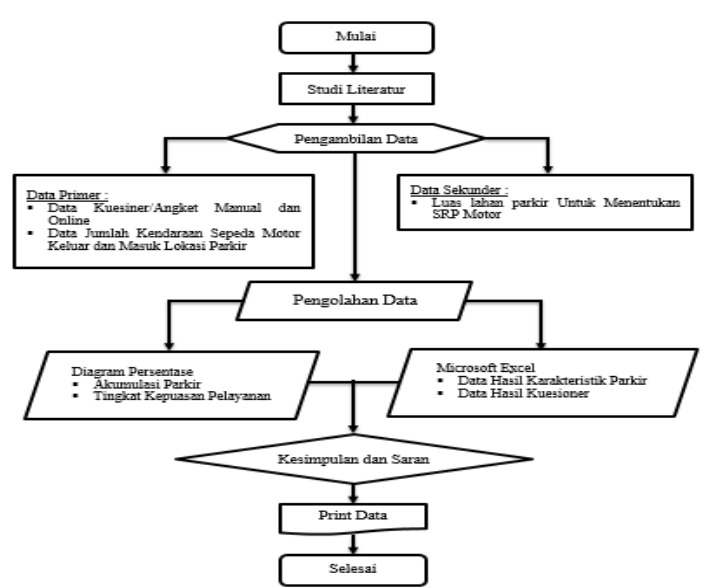

Gambar 1. Metode Penelitian

Berikut adalah lokasi penelitian dan area studi yaitu area parkir di sekitar Stasiun Bogor ditunjukkan pada Gambar 2.

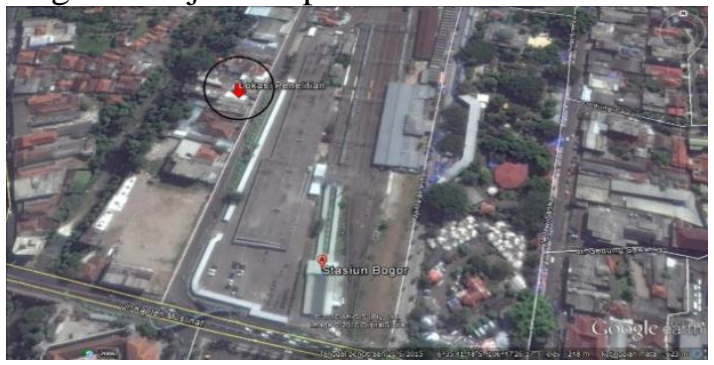

Gambar 2 Lokasi Penelitian

\section{HASIL DAN PEMBAHASAN}

Hasil dari penelitian tentang area ruang parkir di lokasi penelitian dibedakan menjadi dua yaitu parkir motor A dan B. Metode yang digunakan dalam penelitian ini dengan menggunakan Metode Analisis Karakteristik Parkir dan Analisis Tingkat Kepuasan Pelayanan. Survei dilakukan pada tanggal 18, 19, 20, 21, 22, 23, dan 24 Juli 2016. Survei yang dilakukan menggunakan langkah Cordon Count yaitu pengamatan langsung di lapangan dengan pos pengamatan. Survei ini dilakukan dari jam 06:00 sampai jam 22:00. Karakteristik parkir dimaksudkan sebagai sifat - sifat dasar yang memberikan penilaian terhadap pelayanan parkir dan permasalahan parkir yang terjadi pada daerah studi. Berdasarkan karakteristik parkir, akan dapat diketahui kondisi perparkiran yang terjadi pada daerah studi seperti mencakup kapasitas parkir, akumulasi parkir, penggunaan parkir dari tingkat pergantian (Turn Over Paking), volume parkir, dan indeks parkir.
Untuk menentukan kapasitas parkir menggunakan penentuan satuan ruang parkir (SRP).

- Parkir motor $\mathrm{A}=\frac{\text { Luas Area Parkir }}{0,75 \times 2,00}=\frac{614}{1,5}=$ 409,33 409 SRP

- Parkir Motor $\mathrm{B}=\frac{\text { Luas Area Parkir }}{0,75 \times 2,00}=\frac{371}{1,5}=$ $247,33 \approx 247$ SRP

Tabel 1 dibawah memperlihatkan hasil ratarata dari hari penelitian untuk data akumulasi parkir puncak pada lokasi penelitian

Tabel 1. Akumulasi parkir maksimum

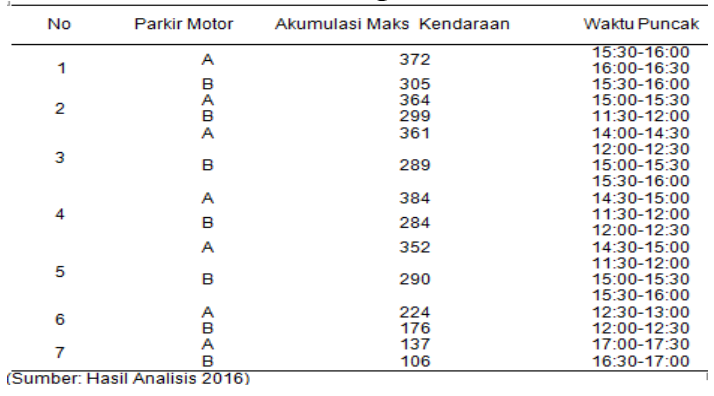

Berdasarkan dari tujuh hari pengamatan akumulasi maksimum terjadi pada Hari Kamis, 21 Juli 2016 sebanyak 384 motor terjadi pada pukul 14:30-15:00 di parkir motor A dan parkir motor B terjadi pada Hari Senin, 18 Juli 2016 sebanyak 305 motor pada pukul 15:30-16:00.

Hasil Penggunaan Ruang Parkir ditinjau dari Parking Turn Over, dibawah ini memperlihatkan tingkat pergantian dan tingkat penggunaan parkir kendaraan.

Tabel 2 Nilai Parking Turn Over Untuk Parkir A

\begin{tabular}{cccc}
\hline No & Kapasitas Parkir (Ruang) & Volume Parkir & Turn Over Parkir \\
\hline 1 & 409 & 414 & 1,012 \\
2 & 409 & 405 & 0,990 \\
3 & 409 & 404 & 0,988 \\
4 & 409 & 411 & 1,005 \\
5 & 409 & 406 & 0,993 \\
6 & 409 & 382 & 0,934 \\
7 & 409 & 337 & 0,824 \\
\hline Jumlah & & 6,746 \\
\hline \multicolumn{2}{c}{ (Sumber : Hasil Analisis, 2016) }
\end{tabular}

Dari tabel di atas kelihatan bahwa parking turn over rata-rata adalah 0,964 untuk data sampel pada saat parkir maksimum.

Tabel 3 Nilai Parking Turn Over Untuk Parkir B

\begin{tabular}{cccc}
\hline No & Kapasitas Parkir (Ruang) & Volume Parkir & Turn Over Parkir \\
\hline 1 & 247 & 360 & 1,457 \\
2 & 247 & 354 & 1,433 \\
3 & 247 & 352 & 1,425 \\
4 & 247 & 351 & 1,421 \\
5 & 247 & 356 & 1,441 \\
6 & 247 & 352 & 1,425 \\
7 & 247 & 323 & 1,308 \\
\hline \multicolumn{2}{c}{ Jumlah } & & 9,911 \\
\hline \multicolumn{2}{l}{ (Sumber: Hasil Analisis 2016) }
\end{tabular}


Dari tabel di atas kelihatan bahwa parking turn over rata-rata adalah 1,416 untuk data sampel pada saat parkir maksimum.

Tabel 4 Volume Harian Parkir Motor A

\begin{tabular}{|c|c|c|}
\hline No & HariTanggal & Volume Parkir Harian \\
\hline & Senin, 18 Juli 2016 & 414 \\
\hline 2 & Selasa, 19 Juli 2016 & 405 \\
\hline 3 & Rabu, 20 Juli 2016 & 404 \\
\hline 4 & Kamis, 21 Juli 2019 & 411 \\
\hline 5 & Jum'at, 22 Juli 2016 & 406 \\
\hline${ }_{7}^{6}$ & $\begin{array}{l}\text { Sabtu, } 23 \text { Jului } 2016 \\
\text { Mingogu 24 Juli } 2016\end{array}$ & $\begin{array}{l}382 \\
337\end{array}$ \\
\hline
\end{tabular}

Tabel diatas menunjukkan bahwa volume tertinggi terjadi pada Hari Senin, 18 Juli 2016 sebanyak 414 motor.

Tabel 5 Volume Harian Parkir Motor B

\begin{tabular}{ccc}
\hline No & Hari/Tanggal & Volume Parkir Harian \\
\hline 1 & Senin, 18 Juli 2016 & 360 \\
2 & Selasa, 19 Juli 2016 & 354 \\
3 & Rabu, 20 Juli 2016 & 352 \\
4 & Kamis, 21 Juli 2019 & 351 \\
5 & Jum'at, 22 Juli 2016 & 356 \\
6 & Sabtu, 23 Juli 2016 & 352 \\
7 & Minggu, 24 Juli 2016 & 323 \\
\hline Sumber:Hasil Analisis 2016)
\end{tabular}

Tabel diatas menunjukkan bahwa volume tertinggi terjadi pada Hari Senin, 18 Juli 2016 sebanyak 360 motor.

Tabel 6 dan Tabel 7 memperlihatkan Rekap Indeks parkir kendaraan pada rata-rata yang ada di lokasi penelitian.

Tabel 6 Indeks Parkir Motor A

\begin{tabular}{ccccc}
\hline No & HariTtanggal & $\begin{array}{c}\text { Kapastitas } \\
\text { Parki }\end{array}$ & Akumulasi Parkir & Indeks Parkir \% \\
\hline 1 & Senin, 18 Juli 2016 & 409 & 372 & 90,954 \\
2 & Selasa, 19 Juli 2016 & 409 & 364 & 88,998 \\
3 & Rabu, 20 Juli 2016 & 409 & 361 & 88,264 \\
4 & Kamis, 21 Juli 2019 & 409 & 384 & 93,888 \\
5 & Jumbat, 22 Juli 2016 & 409 & 352 & 86,064 \\
6 & Sabtu, 23 Juli 2016 & 409 & 224 & 54,768 \\
7 & Mingou, 24 Juli 2016 & 409 & 137 & 33,496 \\
\hline
\end{tabular}

Berdasarkan tabel di atas Indeks parkir maksimum pada waktu puncak maksimum pada hari senin sampai dengan hari minggu kurang dari $100 \%$. Dari nilai parkir yang didapatkan tersebut ternyata area parkir motor di A mampu menampung kebutuhan parkir.

Tabel 7 Indeks Parkir Motor B

\begin{tabular}{ccccc}
\hline No & Hari/Tanggal & Kapasitas Parkir & Akumulasi Parkir & Indeks Parkir \% \\
\hline 1 & Senin, 18 Juli 2016 & 247 & 305 & 123,482 \\
2 & Selasa, 19 Juli 2016 & 247 & 299 & 121,053 \\
3 & Rabu, 20 Juli 2016 & 247 & 289 & 117,004 \\
4 & Kamis, 21 Juli 2019 & 247 & 284 & 114,980 \\
5 & Jum'at, 22 Juli 2016 & 247 & 290 & 117,409 \\
6 & Sabtu, 23 Juli 2016 & 247 & 176 & 71,255 \\
7 & Minggu, 24 Juli 2016 & 247 & 106 & 42,915 \\
\hline \multicolumn{4}{c}{ (Sumber: Hasil Analisis 2016) }
\end{tabular}

Berdasarkan Tabel di atas Indeks parkir maksimum pada waktu puncak maksimum pada hari senin sampai dengan hari jum'at melebihi 100\%. Dari nilai parkir yang didapatkan tersebut ternyata area parkir motor di B tidak mampu menampung kebutuhan parkir yang ada dikarenakan aktifitas yang padat, akan tetapi pada hari sabtu dan minggu indeks parkir kurang dari $100 \%$ masih bisa memenuhi kebutuhan ruang parkir.

\section{Hasil Penentuan Jumlah Sampel}

Tabel 8 Dasar Perhitungan statistik untuk Mencari Kolerasi

\begin{tabular}{rccccc}
\hline \multicolumn{1}{c}{ No } & $X$ & $F$ & $F x$ & $X^{2}$ & $f x^{2}$ \\
\hline 1 & 0.2 & 5 & 1.00 & 0.04 & 0.20 \\
2 & 0.4 & 6 & 2.40 & 0.16 & 0.96 \\
3 & 0.6 & 5 & 3.00 & 0.36 & 1.80 \\
4 & 0.8 & 6 & 4.80 & 0.64 & 3.84 \\
5 & 1 & 8 & 8.00 & 1.00 & 8.00 \\
\hline & Jumlah & 30 & 19.20 & 2.20 & 14.80 \\
\hline
\end{tabular}

Dari jumlah 30 kuesioner sampel diatas dicari deskriptifnya yaitu mean dan standar deviasinya, jadi total jumlah sampel yang dibutuhkan adalah : $325,99 \approx 330$

Pembahasan Hasil Kuesioner Manual Kuesioner manual yang disebar didapatkan $36 \%$ responden mengatakan bahwa parkir di luar Stasiun Bogor lebih praktis dan terjangkau untuk pengguna sepeda motor.

- Prosentase kepuasan pelanggan dengan dimensi tangible indikatornya meliputi kemampuan juru parkir dalam melayani, $35 \%$ menjawab puas, kehandalan juru parkir dalam mengatur/menata kendaraan dengan baik sebesar $49 \%$ menjawab puas, kehandalan fasilitas yang ada di area parkir sebesar 39\% menjawab puas, kehandalan petugas parkir dalam melayani kepadatan area parkir sebesar $47 \%$ menjawab puas. Semua variabel tangible adalah menjawab puas. Indikator dengan persentase terkecil kemampuan juru parkir dalam melayani.

- Prosentase kepuasan pelanggan dengan dimensi reliability indikatornya meliputi kebersihan area parkir sebesar 43\% menjawab kurang puas, tampilan juru parkir dalam bertugas menggunakan pakaian selalu rapih dan sopan sebesar $33 \%$ menjawab kurang puas, ketepatan juru parkir dalam mengelola sistem perparkiran sebesar 50\% menjawab puas, tampilan interior area parkir sebesar $46 \%$ menjawab kurang puas. Semua variabel dari persentase reliability rata-rata adalah kurang puas. Indikator dengan prosentase 
terkecil tampilan juru parkir dalam bertugas menggunakan pakaian selalu rapi dan sopan.

- Prosentase kepuasan pelanggan dengan dimensi responsiveness indikatornya meliputi kemudahan saat memarkirkan kendaraan sebesar $40 \%$ menjawab kurang puas, semua transaksi dilayani atau dilaksanakan dengan cepat dan tepat sebesar 39\% menjawab puas, juru parkir bersedia menolong pengguna jasa parkir ketika mengalami kesulitan saat area parkir dalam keadaan penuh sebesar $43 \%$ menjawab kurang puas, juru parkir tidak menunjukan kesan sibuk dalam menyapa pengguna jasa parkir sebesar 44\% menjawab kurang puas. Semua variabel dari persentase responsiveness rata-rata adalah kurang puas. Indikator dengan persentase terkecil semua transaksi dilayani atau dilaksanakan dengan cepat dan tepat.

- Berdasarkan dari persentase kepuasan pelanggan dengan dimensi assurance indikatornya meliputi adanya sistem pengamanan parkir yang baik sebesar 47\% menjawab kurang puas, kesopanan juru parkir sebesar $43 \%$ menjawab kurang puas, keramahan juru parkir sebesar $48 \%$ menjawab puas, kejujuran juru parker sebesar 50\% menjawab puas. Semua variabel dari persentase assurance ratarata adalah puas. Indikator dengan persentase terkecil kesopanan juru parkir.

- Berdasarkan dari prosentase kepuasan pelanggan dengan dimensi empathy indikatornya meliputi juru parkir mengucapkan salam pembuka (selamat pagi/siang/malam) pada awal pelayanan sebesar 38\% menjawab kurang puas, juru parkir selalu mengucapkan terima kasih di akhir pelayanan sebesar 38\% kurang puas, kemudahan mencari ruang untuk parkir sebesar $35 \%$ menjawab kurang puas, kenyamanan di area parkir sebesar 38\% menjawab puas. Semua variabel dari persentase empathy rata-rata adalah kurang puas. Indikator dengan persentase terkecil kemudahan mencari ruang untuk parkir.

Pembahasan Hasil Kuesioner Online

Prosentase dari kuesioner online menunjukkan $63 \%$ responden mengatakan bahwa parkir di luar Stasiun Bogor lebih praktis dan lebih mudah untuk pengguna kendaraan motor.

- Prosentase kepuasan pelanggan dengan dimensi tangible indikatornya meliputi kemampuan juru parkir dalam melayani sebesar 52,6\% menjawab puas, kehandalan juru parkir dalam mengatur/menata kendaraan dengan baik sebesar 52,6\% menjawab puas, kehandalan fasilitas yang ada di area parkir sebesar $52,6 \%$ menjawab puas, kehandalan petugas parkir dalam melayani kepadatan area parkir sebesar $42,1 \%$ menjawab puas. Semua variabel tangible adalah puas. Indikator dengan persentase terkecil kehandalan petugas parkir dalam melayani kepadatan area parkir.

- Berdasarkan prosentase kepuasan pelanggan dengan dimensi reliability indikatornya meliputi kebersihan area parkir sebesar 52,6\% menjawab puas, tampilan juru parkir dalam bertugas menggunakan pakaian selalu rapih dan sopan sebesar $42,1 \%$ menjawab kurang puas, ketepatan juru parkir dalam mengelola sistem perparkiran sebesar $68,4 \%$ menjawab puas, tampilan interior area parkir sebesar 52,6\% menjawab puas. Semua variabel dari persentase reliability rata-rata adalah puas. Indikator dengan persentase terkecil tampilan juru parkir dalam bertugas menggunakan pakaian selalu rapih dan sopan.

- Kepuasan pelanggan dengan dimensi responsiveness indikatornya meliputi kemudahan saat memarkirkan kendaraan sebesar $47,4 \%$ menjawab puas, semua transaksi dilayani atau dilaksanakan dengan cepat dan tepat sebesar $31,6 \%$ menjawab kurang puas, juru parkir bersedia menolong pengguna jasa parkir ketika mengalami kesulitan saat area parkir dalam keadaan penuh sebesar $36,8 \%$ menjawab puas, juru parkir tidak menunjukan kesan sibuk dalam menyapa pengguna jasa parkir sebesar 47,4\% menjawab puas. Semua variabel dari persentase responsiveness rata-rata adalah puas. Indikator dengan persentase terkecil semua transaksi dilayani atau dilaksanakan dengan cepat dan tepat.

- Prosentase kepuasan pelanggan dengan dimensi assurance indikatornya meliputi adanya sistem pengamanan parkir yang 
baik sebesar 36,8\% menjawab kurang puas, kesopanan juru parkir sebesar 47,4\% menjawab puas, keramahan juru parkir sebesar 52,6\% menjawab puas, kejujuran juru parkir sebesar $68,4 \%$ menjawab puas. Semua variabel dari persentase assurance rata-rata adalah puas. Indikator dengan persentase terkecil adanya sistem pengamanan parkir yang baik.

- Kepuasan pelanggan dengan dimensi empathy indikatornya meliputi juru parkir mengucapkan salam pembuka (selamat pagi/siang/malam) pada awal pelayanan sebesar $42,1 \%$ menjawab kurang puas, juru parkir selalu mengucapkan terima kasih di akhir pelayanan sebesar 36,8\% menjawab puas, kemudahan mencari ruang untuk parkir sebesar 42,1\% menjawab puas, kenyamanan di area parkir sebesar 47,4\% menjawab puas. Semua variabel dari persentase empathy rata-rata adalah puas. Indikator dengan persentase terkecil juru parkir selalu mengucapkan terima kasih di akhir pelayanan.

\section{KESIMPULAN}

- Luas area parkir yang digunakan untuk lahan parkir sebesar $614 \mathrm{~m}^{2}$ dengan 409 SRP untuk parkiran A dan $371 \mathrm{~m}^{2}$ dengan 247 SRP untuk parkiran B.

- Dari hasil tujuh hari pengamatan akumulasi maksimum terjadi pada Hari Kamis, 21 Juli 2016 sebanyak 384 motor terjadi pada pukul 14:30-15:00 di parkir motor A dan parkir motor B terjadi pada Hari Senin, 18 Juli 2016 sebanyak 305 motor pada pukul 15:30-16:00.

- Dengan penggunaan ruang parkir ditinjau dari parking turn over pada parkir motor A kebutuhan parkir mencukupi daya tampung sedangkan pada parkir motor B kebutuhan parkir melebihi daya tampung.

- Jumlah volume kendaraan maksimum pada parkir motor A mencapai 414 motor dan 360 motor pada parkir motor B masing-masing terjadi pada Hari Senin. Indeks parkir maksimum di parkir motor A pada waktu puncak maksimum pada hari senin sampai dengan hari minggu kurang dari $100 \%$ sedangkan di parkir motor B pada waktu puncak maksimum pada hari senin sampai dengan hari jum'at melebihi $100 \%$ akan tetapi pada hari sabtu dan minggu indeks parkir kurang dari $100 \%$.

- Kuesioner manual menunjukkan 36\% responden mengatakan bahwa parkir di luar Stasiun Bogor lebih praktis dan terjangkau untuk pengguna sepeda motor sedangkan online menunjukkan $63 \%$ responden mengatakan bahwa parkir di luar Stasiun Bogor lebih praktis dan lebih mudah untuk pengguna kendaraan motor.

\section{DAFTAR PUSTAKA}

Abubakar, I. 1998. Sistem Transportasi Kota. Direktorat Bina Sistem Lalu Lintas dan Angkutan Kota, Jakarta.

A.I. Syahidina, A. Goeritno and Syaiful, 2017. "Penggunaan System Dynamics Software Untuk Simulasi Model Kebijakan Perburuan Rusa," di Prosiding Seminar Nasional Multidisiplin Ilmu (SENMI) VIII, 2017, Universitas Budi Luhur, Jakarta, hlm. ICT- 210 - ICT- 217.

Direktorat Jenderal Perhubungan Darat. 1996. Pedoman Teknis Peyelenggaraan Fasilitas Parkir. Jakarta.

Direktorat Jenderal Perhubungan Darat. 1998. Pedoman Perencanaan dan Pengoperasian Fasilitas Parkir. Jakarta.

Hermawan, Warsito. 1995. Pengantar Metodologi Penelitian Sosial. Surabaya: Airlangga University Press.

Hobbs, F. D., 1995, Perencanaan dan Teknik Lalu Lintas, Edisi Kedua, Gadjah Mada University Press, Yogyakarta.

Kotler, Philips dan Keller, Kevin Lane. 2008. Manajemen Pemasaran. Jilid 1 dan 2. Edisi 12. PT. Indeks.

Kotler, Philips. 2000. Manajemen Pemasaran. PT. Prenhallindo. Jakarta.

Marzuki, 1997. Metodologi Riset. BPFE. Universitas Islam Indonesia. Yogyakarta.

Menteri Permukiman dan Prasarana Wilayah, 2001, Pedoman Penentuan Standar Pelayanan Minimal Bidang Penataan Ruang, Perumahan Dan Permukiman Dan Pekerjaan Umum.

Oppenlender J.C and P.C. Box. 1976. Manual of Traffic Engineering Studies. Institute of Transportation Engineering Washington DC. 
Peraturan Daerah Kota Bogor, Tentang tarif Parkir SK No 6/2008, tahun 2008.

Peraturan Daerah Kota Bogor, 2012, Tentang tarif Parkir Baru di Jalan Surya Kencana SK No 4/2012, bulan Juli 2012.

Raharjo, A.D.A. 2011. Analisis Kapasitas Ruang Parkir RSUD Dr. R. Koesma Tuban-Jawa Timur. Skripsi Jurusan Teknik Sipil, Fakultas Teknik Universitas Atma Jaya Yogyakarta.

SYAIFUL, SYAIFUL (2005) ANALISIS KEBISINGAN ARUS LALU LINTAS DAN GEOMETRI JALAN DI KAWASAN SIMPANG LIMA KOTA SEMARANG. Masters thesis, program Pascasarjana Universitas Diponegoro. Diponegoro University, INSTITUTIONAL REPOSITORY.

Syaiful, S., \& Elvira, Y. (2017). Case Study On Use Area Parking At New Market City Shopping Center Bogor. IJTI (International Journal of Transportation And Infrastructure), 1(1), 34-40. Retrieved from http://jurnal.narotama.ac.id/index.php/ijt i/article/view/330

Syaiful, S., \& Rulhendri, R. (2014). ROAD MAP KEBISINGAN YANG DITIMBULKAN KENDARAAN BERMOTOR DI KOTA BOGOR (KAJIAN SEKSI II UNTUK KASUS DI DEPAN RSUD CIAWI BOGOR). Prosiding Forum Studi Transportasi Antar Perguruan Tinggi, 2(1). Retrieved from https://jurnal.unej.ac.id/index.php/PFST PT/article/view/2939
Syaiful, 2015, "Tingkat Kebisingan Akibat Kendaraan Bermotor Di Depan Rumah Sakit Hermina Bogor," di Seminar Nasional Teknik Sipil V 2015, Universitas Muhammadiyah Surakarta. https://publikasiilmiah.ums.ac.id/handle/ 11617/6479?show=full

[Syaiful, S.T., M.T. (2016); Noise Analysis Caused by Vehicle Speed in front of RS PMI BOGOR Int. J. of Adv. Res. 4 (1). 772-779] (ISSN 2320-5407). http://www.journalijar.com/article/7687/ noise-analysis-caused-by-vehicle-speedin-front-of-rs-pmi-bogor/

Tobing, David M.L . 2007. Parkir dan Perlindungan Hukum Konsumen. PT. Timpaui Agung: Jakarta.

Undang-Undang Republik Indonesia Nomor 25 Tahun 2009 Tentang Pelayanan Publik, Jakarta, 2009.

Warpani S, 1990. Rekayasa Lalu Lintas. Bhatara Karya Aksara, Jakarta.

Z. Tamin, Ofyar. 1997. Perencanaan dan Pemodelan Transportasi. Bandung: Jurusan Teknik Sipil Institut Teknologi Bandung. 